\title{
PENYALUTAN BAKTERI ASAM LAKTAT MENGGUNAKAN NANOPARTIKEL KITOSAN
}

\author{
Gabriella Nathalie Sumeisey ${ }^{1)}$, Stella Deiby Umboh ${ }^{1)}$, Trina Ekawati Tallei ${ }^{1)}$ \\ ${ }^{1)}$ Program Studi Biologi FMIPA UNSRAT Manado, 95115
}

\begin{abstract}
The lactic acid bacteria (LAB) are bacteria which have large contribution to provide functional benefits for the human body as a probiotic. One of the conditions needed for a bacterium to be catagorized as probiotic, is to be tolerant to low $\mathrm{pH}$. The encapsulation approach using chitosan nanoparticles is one of the methods to prevent damage and the amount of probiotic bacteria reduction when they are exposed to low $\mathrm{pH}$. Chitosan is a natural polymer, biocompatible, biodegradable, and not toxic substance, and can form microencapsulation with cross-bonding with tripolyphosphate. Therefor, chitosan is suitable for encapsulation of lactic acid bacteria.
\end{abstract}

Keywords : Lactitc acid bacteria, chitosan, microencapsulation, viability, pH low

\begin{abstract}
ABSTRAK
Bakteri asam laktat merupakan bakteri yang memiliki kontribusi besar dalam memberikan manfaat fungsional bagi tubuh manusia sebagai probiotik. Salah satu syarat yang dibutuhkan agar suatu bakteri dinyatakan sebagai probiotik yaitu toleransi terhadap $\mathrm{pH}$ rendah. Pendekatan penyalutan (enkapsulasi) nanopartikel kitosan merupakan salah satu metode untuk mencegah kerusakan dan berkurangnya jumlah bakteri probiotik ketikan terpapar pada $\mathrm{pH}$ rendah. Kitosan merupakan polimer alami, biokompatibel, biodegradable, tidak beracun, dan dapat membentuk ikatan silang dengan tripolifosfat, sehingga kitosan dapat digunakan sebagai matriks pada mikroenkapsulasi (penyalutan mikro) bakteri asam laktat.
\end{abstract}

Kata kunci : bakteri asam laktat, kitosan, mikroenkapsulasi, 


\section{PENDAHULUAN}

Bakteri asam laktat (BAL) merupakan jenis bakteri Gram negatif, tidak membentuk spora, dan berbentuk kokus, cocobacilli, atau basil (Rembulan 2015). Bakteri-bakteri ini mampu menghasilkan asam laktat, hidrogen peroksida, dan beberapa hasil metabolisme berupa asam-asam organik yang bermanfaat bagi kesehatan yang dihasilkan dari fermentasi karbohidrat (Indriyati, 2010; Bawole et al., 2018).

Bakteri asam laktat berkontribusi besar memberikan manfaat fungsional bagi tubuh manusia sebagai bakteri probiotik (Halim dan Zubaidah, 2013). Bakteri-bakteri ini ada yang dapat dikembangkan menjadi probiotik. Bakteri probiotik merupakan BAL yang hidup di dalam usus, bersimbiosis dengan mikroflora usus yang mampu melawan bakteri patogen di dalam usus, oleh karena itu pemberian probiotik dapat berpengaruh menguntungkan bagi kesehatan (Agus, 2016). Manfaat terapeutik yang dimiliki oleh probiotik membantu pengobatan intoleraansi laktosa, mencegah kanker usus besar, menurunkan jumlah kolesterol dalam darah (Halim dan Zubaidah, 2013).

Menurut Harjuni dan Mulyadi (2016), beberapa syarat yang diperlukan untuk suatu bakteri dapat dikatakan probiotik adalah antagonismenya terhadap bakteri patogen dan toleransi terhadap $\mathrm{pH}$ rendah. Bakteri calon probiotik harus mampu hidup pada kondisi asam, karena probiotik efektif jika sudah terseleksi terhadap asam. Kebanyakan bakteri asam laktat tidak hanya tumbuh lebih lambat pada $\mathrm{pH}$ rendah, tetapi mungkin mengalami kerusakan dan hilangnya viabilitas. Enkapsulasi merupakan salah satu metode untuk mencegah kerusakan dan berkurangnya jumlah bakteri probiotik dan dapat membuat probiotik untuk bertahan pada $\mathrm{pH}$ rendah. Penelitian ini berupa kajian pustaka yang bertujuan untuk memaparkan pendekatan enkapsulasi untuk melindungi BAL dengan menggunakan nanopartikel kitosan.

\section{METODOLOGI PENELITIAN}

Penelitian ini merupakan kajian pustaka yang dilakukan selama 2 bulan dari bulan Juli sampai dengan Agustus. Kajian pustaka adalah kegiatan yang melibatkan pencairan dan penelaahan artikel-artikel ilmiah sebagai bahan pustaka yang memuat hasil-hasil penelitian terdahulu. Kajian pustaka dilakukan untuk membangun konsep yang menjadi dasar dalam tulisan ini.

\section{HASIL DAN PEMBAHASAN}

\section{Enkapsulasi}

Enkapsulasi (penyalutan) merupakan proses pembentukan salut dari suatu partikel untuk mencapai efek tertentu yang diinginkan, seperti imobilitas atau isolasi perlindungan atau stabilisasi, pelepasan terkontrol, dan perubahan sifat fisik (Chan et al., 2011), proses pembentukan lapisan dengan matrik hingga bagian dalam terlapisi seluruhnya, dan terbentuk dinding kapsul (Junaidi, 2018). Enkapsulasi probiotik telah diteliti untuk meningkatkan kelangsungan hidup mereka dalam produk makanan dan saluran usus (Kholiso, 2016). Enkapsulasi ditunjukkan untuk menstabilkan sel, berpotensi untuk meningkatakan kelangsungan dan stabilitas mereka selama produksi, penyimpanan dan penanganan (Gbassi dan Vandamme, 2012). Bahan inti dalam proses enkapsulasi dapat berupa senyawa atau BAL. Produk yang dihasilkan dari proses mikroenkapsulasi dinamakan mikrokapsul (Poshadri dan Aparna, 2010). Enkapsulasi dapat meningkatkan 
viabilitas bakteri probiotik dibandingkan dengan sel bebas tanpa enkapsulasi. (Chandra-mouli et al., 2003).

$$
\text { Banyak faktor yang }
$$

mempengaruhi keberhasilan proses enkapsulasi seperti sifat fisikokimia bahan inti dan bahan penyalut, serta tahapan dalam enkapsulasi (Marzuki, 2012). Enkapsulasi dikatakan berhasil jika bahan yang dienkapsulasi memiliki viabilitas sel yang relatif tinggi dan sifatsifat fisiologis yang relatif sama dengan sebelum dienkapsulasi (Master, 1997).

Bahan penyalut yang digunakan untuk enkapsulasi harus mampu memberikan suatu lapisan tipis yang kohesif dengan bahan inti, dapat bercampur secara kimia dan tidak bereaksi dengan bahan inti. Menurut Ningsih et al. (2017), enkapsulasi berbasis nanopartikel merupakan pendekatan yang efektif dalam memasukkan senyawa bioaktif dalam bahan pangan. Kitosan telah terbukti dapat dijadikan sebagai penyalut karena memiliki keunggulan, seperti bersifat non-toksik, baik dalam pengantaran obat, biodegradable, dan biocompatible, serta memiliki aktivitas sebagai antibakteri (Amaliyah et al., 2018).

\section{Nanopartikel Kitosan}

Aplikasi nanoteknologi bertujuan untuk menghasilkan material berskala nanometer, mengeksplorasi, dan merekayasa karakteristik material tersebut, serta mendesain ulang material tersebut ke dalam bentuk, ukuran, dan fungsi yang diinginkan (Irianto dan Muljanah, 2011). Nanopartikel merupakan partikel koloid padat dengan diameter 1-1000 nm yang mengandung makromolekuler material dan dapat digunakan untuk pengobatan sebagai penghantar bat yang senyawa aktifnya telah terlarut, terjerat, dan tersalut (Kurniasari dan Sri, 2017).
Polimer yang memudahkan dalam penyiapan nanopartikel dapat dipilih berupa polimer yang larut air (Irianto dan Muljanah, 2011), misalnya kitosan (Harahap, 2012), Nanokitosan merupakan kitosan yang memiliki pertikel yang berbentuk padat dengan ukuran sekitar 10 - $1000 \mathrm{~nm}$ yang terlarut dan terdispersi (Luntungan et al., 2018). Nanopartikel dari bahan polimer yang biodegradable dan biokompatibel merupakan salah satu bahan yang baik untuk penghantar obat karena mudah terserap secara utuh di dalam sistem pencernaan setelah masuk ke dalam tubuh (Wahyono 2010). Hasil penelitian memperlihatkan bahwa kitosan memiliki kemampuan untuk membuka secara sementara kait antar sel (tight junction) pada membran usus (Bhardwaj dan Kumar, 2006; Martien et al., 2008).

Kitosan merupakan biopoli amino sakarida linear alami yang diperoleh dari deasetilasi kitin (Mardy et al., 2016), mempunyai rantai tidak linier dengan rumus $\left(\mathrm{C}_{6} \mathrm{H}_{11} \mathrm{NO}_{4}\right) \mathrm{n}$, tidak berbau, dan berwarna putih (Rachmania, 2011). Kitosan merupakan partikel akhir yang terbentuk yang dipengaruhi oleh derajat deasetilasi, derajat substitusi, dan berat molekul dari karbosimetil kitosan tersebut (Jayakumar et al., 2010).

Menurut Ningsih et al., (2017), pendekatan efektif dalam memasukkan senyawa bioaktif dalam bahan pangan yaitu dengan enkapsulasi berbasi nanopartikel. Menurut Ahmad et al., (2012), enkapsulasi nanopartikel bertujuan untuk meningkatkan kelarutan karena luas permukaannya yang besar, mengontrol pelepasan zat bioaktif dalam tubuh, dan melindungi dari interaksi dengan zat lain dalam bahan pangan.

Salah satu material atau bahan penyalut yang mendapat perhatian dalam nanoteknologi karena memiliki sifat yang khas yaitu kitosan (Talu'mu, 2011). Kitosan merupakan polisakarida yang dapat diperoleh dari deasetilasi kitin 
(Ayumi, 2018). Kitosan mempunyai beberapa sifat yang menguntungkan seperti anti mikroba, wound healing, tidak beracun, murah, biokompatibel, biodegradable, dan larut dalam air. Dalam bentuk mikro/nanopartikel kitosan mempunyai banyak keunggulan yakni tidak toksik dan stabil selama penggunaan (Mannuela, 2016).

Beberapa metode telah digunakan untuk membuat sistem partikulat kitosan. Penentuan metode yang digunakan tergantung faktor-faktor seperti ukuran partikel yang diinginkan, stabilitas kimia dan panas dari bahan aktif, reprodusibilitas profil kinetic pelepasan produk akhir dan toksisitas residu yang terkait dengan produk akhir (Agnihotri et $a l ., 2004)$. Nanopartikel terdiri dari bahan makromolekul dan dapat digunakan untuk terapi sebagai pembantu (adjuvant) vaksin atau pembawa obat, yaitu dengan melarutkan, memerangkap, mengenkapsulasi, menyerap atau menempelkan bahan aktif secara kimia. Polimer yang digunakan untuk membentuk nanopartikel dapat berupa polimer sintetik dan alami (Irianto dan Muljanah, 2011).

\section{Bakteri Asam Laktat Sebagai Probiotik}

Menurut FAO (Food and Agriculture Organization) (2002), probiotik didefinisikan sebagai mikroorganisme hidup yang bila diberikan dalam jumlah yang cukup akan memberikan manfaat kesehatan pada inangnya. Beberapa manfaat positif probiotik terhadap kesehatan antara lain dapat meningkatkan ketahanan terhadap penyakit terutama infeksi usus dan diare, meningkatkan imunitas tubuh membantu dalam pencernaan, mencegah kanker usus besar (Masood et al., 2011), menurunkan gula darah (Iqbal et al., 2014), dan menurunkan kolesterol (Kumar et al., 2012).

Beberapa spesies BAL setelah diteliti mempunyai potensi sebagai probiotik (Maunatin, 2012). Bakteri asam laktat dapat ditemukan dalam bahan pangan (Wikandari et al., 2012), serta saluran gastrointestinal dan urogenital manusia dan hewan.

Strain BAL probiotik harus dapat bertahan melewati saluran pencernaan dan dapat mengkolonisasi usus untuk waktu yang lama sampai mendapatkan suatu efek bagi kesehatan (Tambunan, 2016). Kebanyakan BAL tidak hanya tumbuh lebih lambat pada $\mathrm{pH}$ rendah, tetapi mungkin mengalami kerusakan dan hilangnya viabilitas jika selnya berada pada kondisi $\mathrm{pH}$ yang rendah. Kondisi yang sangat asam dapat mengakibatkan kerusakan membran dan lepasnya komponen intraseluler dan menyebabkan kematian bakteri (Harjuni dan Mulyadi, 2016).

\section{Enkapsulasi Probiotik}

Salah satu cara meningkatkan viabilitas bakteri probiotik adalah dengan proses enkapsulasi. Metode enkapsulasi yang digunakan adalah metode ekstruksi untuk menghindari suhu ekstrim saat proses enkapsulasi yang dapat megurangi jumlah maupun viabilitas bakteri. Metode enkapsulasi probiotik yang dipilih yaitu metode ekstrusi dan metode gelasi ionik. Metode ekstrusi dipilih karena selain menggunakan alat sederhana berupa jarum suntik, metode ini juga dipilih dengan tujuan untuk menghindari suhu dan tekanan yang ekstrim pada metode spray drying (Anal dan Singh, 2007). Metode gelasi ionik dikarenakan prosesnya yang sederhana, tidak menggunakan pelarut organik, dan dapat dikontrol dengan mudah (Mardliyati et al., 2012).

Beberapa penelitian telah membuktikan bahwa bakteri probiotik dapat bertahan hidup setelah dienkapsulasi menggunakan nanopartikel kotosan. Hal ini 
disebabkan karena efisiensi enkapsulasi meningkat secara signifikan dengan meningkatnya konsentrasi biopolimer (Castilla et al., 2010). Viabilitas probiotik terenkapsulasi nanokitosan masih tinggi walaupun setelah diinkubasi pada $\mathrm{pH}$ rendah meskipun jumlah populasinya cenderung mengalami sedikit penurunan. Penurunan jumlah bakteri yang terjadi pada simulasi cairan asam lambung dikarenakan $\mathrm{pH}$ lambung yang sangat asam yang akan mempengaruhi kekuatan polimer natrium alginat-kitosan sebagai matriks enkapsulasi bakteri asam laktat. (Ardianto, 2011)

\section{KESIMPULAN}

Bakteri asam laktat dapat dienkapsulasi dengan nanopartikel kitosan dengan metode ekstrusi yang akan menghasilkan mikrokapsul.

\section{SARAN}

Perlu adanya penelitian lanjut mengenai berbagai metode enkapsulasi probiotik.

\section{DAFTAR PUSTAKA}

Agnihotri, S.A., Mallikarjuna, N.N. and Aminabhavi, T.M. 2004. Recent advances on chitosan-based microand nanoparticles in drug delivery. Journal of controlled release. 100(1) :5-28.

Agus, A. 2016. Kemampuan Tumbuh Isolat Bakteri Asam Laktat Asal Saluran Pencernaan Broiler Umur Tiga Hari Pada Berbagi Uji Probiotik [skripsi]. FMIPA UINA, Makasar.

Anal, A.K. dan Singh, H. 2007. Recent advances in microencapsulation of probiotics for industrial applications and targeted delivery. Trends in Food Science \& Technology. 18, 240-251.
Amaliyah, N. 2016. Enkapsulasi Asam Sinamat dalam Nanopartikel Kitosan Sebagai Antibakteri. Prosiding Seminar Nasional Sains dan Enterpreneurship III Tahun 2016; Semarang, 20 Agustus 2016. Reorientasi Bioteknologi dan Pembelajarannya Untuk Menyiapkan Generasi Indonesia Emas Berlandaskan Entrepreneurship. Hlm 552-559.

Ardianto A. 2011. Enkapsulasi Lactobacillus acidophilus casei Dengan Teknik Ekstruksi Sebagai Starter Untuk Pembuatan Dadih Susu Sapi. IPB. 1

Ayumi, D. 2018. Pembuatan Dan Karakterisasi Nanopartikel Ekstrak Etanol Daun Ekor Naga (Rhaphidophora pinnata (L.f.) Schott) Menggunakan Metode Gelasi Ionik [skripsi]. Fakultas Farmasi USU, Medan.

Bawole, K.V., Umboh. S.D., and Tallei. T.E. 2018. Uji Ketahanan Bakteri Asam Laktat Hasil Fermentasi Kubis Merah (Brassica oleracea L.) Pada pH 3. Jurnal Mipa Unsrat Online. 7(2): 20-23.

Castilla, O.S., Calleros C.L., Galindo, H,S,G., Ramirez. J.A. and Carter. 2010. Textural properties of alginate-pectin MLN and survivability of entrapped Lb. Casei in simulated gastrointestinal condition and in yoghurt. Food Research International. 111-117.

Chandra mouli, V., Kailasapathy, K., Peiris, P. and Jones, M., 2003. An improved method of microencapsulation and its evaluation to protect Lactobacillus spp. in simulated gastric conditions. Journal of 
microbiological methods, 56(1): 27-35.

Chan, E.S., Wong. S.L., Lee. P.P., Lee. J.S., Ti. T.B., Zhang. Z., Poncelet. D., Ravindra. P., Phan. S.H., and Yim. Z.H. 2011. Effects of starch filler on the physical properties of lyophilized calcium-alginate beads and the viability of encapsulated cells. Carbohydrate Polymers. 83(1): 225-232.

Gbassi, G.K., and Vandamme. T., 2012. Probiotic encapsulation technology: from microencapsulation to release into the gut. Pharmaceutics. 4(1): 149163.

Halim, C.N., dan Zubaidah. E. 2013. Studi kemampuan probiotik isolat bakteri asam laktat penghasil eksopolisakarida tinggi asal sawi asin (Brassica juncea). Jurnal Pangan dan Agroindustri.1(1): 129-137.

Harahap, Y. 2012. Preparasi dan Karakterisasi Nanopartikel Kitosan Dengan Variasi Asam. [skripsi]. Fakultas Teknik UI, Depok.

Harjuni, F., and Mulyadi. A. 2016. Tolerance of Probiotic Bacterial Candidate From Kakap Putih on $\mathrm{Ph}$ and Bile Salt. Jurnal Online Mahasiswa Fakultas Perikanan dan Ilmu Kelautan Universitas Riau. 3(2): 1-10.

Indriyati, A.S. 2010. Isolasi Dan Karakterisasi Bakteri Asam Laktat (BAL) Dari Susu Formula Balita Yang Berpotensi Menghasilkan Substansi Antimikroba [skripsi]. Falkutas
Sains dan Teknologi UINSK, Yogyakarta.

Iqbal, M.Z., Qadir. M.I., Hussain. T., Janbaz. K.H., Khan. Y.H., and Ahmad. B. 2014. Probiotics and their beneficial effects against various diseases. Pak. J.Pharm.Sci. 27(2):405-415.

Irianto, H.E., dan Muljanah. I. 2011. Proses dan aplikasi nanopartikel kitosan sebagai penghantar obat. Squalen: Buletin Pascapanen dan Bioteknologi Kelautan dan Perikanan. 6(1): 18. Fakultas Farmasi USU, Medan.

Jayakumar. R., Prabaharam. M., Naair.S.V., Tokura. S., Tamura. H., Selvamurugan. N. 2010. Novel carboxymethyl derivatives of chitin and hitosan materials antheir biomedical applications. Progress in Material Science. 55: 675-709.

Junaidi, M. 2018. Uji Viabilitas Mikroenkapsulasi Lactobacillus acidophilus Menggunakan Polimer Natrium Alginat-Kitosan Terhadap Simulasi Cairan Asam Lambung [tesis]. Fakultas Farmasi USU, Medan.

Kholisoh, G. 2016. Uji Viabilitas Enkapsulasi Lactobacillus casei Menggunakan Matriks Kappa Karagenan Terhadap Simulasi Cairan Asam Lambung [skripsi]. Fakultas Kedoktersan Dan Ilmu Kesehatan, UIN Syarif Hidayatullah, Jakarta.

Kurniasari, D., dan Atun. S., 2017. Pembuatan dan Karakterisasi Nanopartikel Ekstrak Etanol Temu Kunci (Boesenbergia pandurata) pada Berbagai Variasi 
Komposisi Kitosan. Jurnal Sains

Dasar. 6(1): 31-35.

Luntungan, A.H., Mandey. L.C., Rumengan. I.F., and Suptijah, P. 2018. The Effects of Nanochitosan Coating to Phenolic Compounds of Basil Leaf (Ocimum basilicum L) Extracts. Jurnal Ilmu dan Teknologi Pangan. 5(2): 20-25.

Mardliyati, E., Muttaqien. S.E., dan Setyawati. D.R. 2012. Sintesis Nanopartikel Kitosan-Trypoly Phosphate dengan Metode Gelasi Ionik: Pengaruh Konsentrasi dan Rasio Volume Terhadap Karakteristik Partikel. Prosiding Pertemuan Ilmiah Ilmu Pengetahuan dan Teknologi Bahan; Serpong, 3 Oktober 2012. Hlm 90-93.

Mardy, D.C., Sudjari. S., dan Rahayu. S.I. 2016. Perbandingan Efektivitas Kitosan (2-Acetamido2-Deoxy-D-Glucopyranose) dan Nano Kitosan terhadap Pertumbuhan Bakteri Enterococcus faecalis secara In Vitro. Majalah Kesehatan FKUB. 2(4): 229-240.

Martien, R., Loretz. B., Sandbichler. A.M., BernkopSchnürch. A. 2008. Thiolated chitosan nanoparticles: transfection study in the Caco-2 differentiated cell culture. Nanotech., 19: 1-9.

Marzuki, Ismail. 2012. Pelepasan Terkendali Kalium Klorida dalam Mikrosfer Kitosan dengan Metode Tautan Silang [skripsi]. FT UI, Depok.

Master, K., 1997. Spray drier. Baker, CGJ Industrial Drying for Foods. 1st ed. London: Academic and Profesional.

Masood, M. I., Qadir. M. I., Shirazi. J.H., and Khan, I.U. 2011. Beneficial effects of Lactic Acid Bacteria on human beings. Critical Rev.Microb.37(1): 91-98.

Maunatin, A., dan Khanifa. K. 2013. UJI POTENSI PROBIOTIK Lactobacillus Plantarium SECARA IN VITRO. Alchemy.2(1): 26-34.

Ningsih, N., S. Yasni., S. Yuliani. 2017. Sintesis Nanopartikel Ekstrak Kulit Manggis Merah dan Kajian Sifat Fungsional Produk Enkapsulasinya. J.Teknol. dan Industri Pangan. 28(1): 27-35.

Poshadri, A., dan Aparna Kuna. 2010. Microencapsulation Technolog: A Review. J.Res. Angrau. 38(1):86102.

Rachmania, D. 2011. Karakteristik Nano Kitosan Cangkang Udang Vannamei (Litopenaeus vannamei) Dengan Metode Gelasi Ionik [skripsi]. FPIK ITB, Bogor.

Rembulan, G. D., Sunarti. T. C., and Meryandini. $\quad$ A. 2015. Penambahan Bakteri Asam Laktat Terenkapsulasi Untuk Menekan Pertumbuhan Bakteri Patogen Pada Proses Produksi Tapioka. Jurnal Teknologi dan Industri Pangan. 26(1): 34-43.

Talu'mu, M. D. 2016. Sintesis Kitosan Nanopartikel dengan Metode Sonokimia, Gelasi Ionotropik, dan Kompleks Polielektrolit. Jurnal Progres Kimia Sains, 1(2): 130137. 
PHARMACON- PROGRAM STUDI FARMASI, FMIPA, UNIVERSITAS SAM RATULANGI,

Tambunan, A. 2016. Karakteristik Probiotik Berbagai Jenis Bakteri Asam Laktat (Bal) Pada Minuman Fermentasi Laktat Sari Buah Nanas [skripsi]. Fakultas Pertanian Universitas Lampung, Bandar Lampung.

Wahyono, D. 2010. Ciri nanopartikel kitosan dan pengaruhnya pada ukuran partikel dan efisiensi penyaluran ketoprofen [tesis]. Program Pascasarjana IPB, Bogor.

Wikandari, P. R., Marsono. Y., and Rahayu, E.S., 2012. Karakterisasi bakteri asam laktat proteolitik pada bekasam. Jurnal Natur Indonesia. 14(02): 120-125. 